\title{
Efficient Protein Refolding Using Surfactants at High Final Protein Concentration
}

\author{
Hidetaka Noritomi*, Yoshiyuki Kato, Satoru Kato \\ Department of Applied Chemistry, Tokyo Metropolitan University, Tokyo, Japan. \\ Email: ${ }^{*}$ noritomi@tmu.ac.jp
}

Received December $11^{\text {th }}$, 2013; revised January $2^{\text {nd }}$, 2014; accepted January $13^{\text {th }}, 2014$

Copyright (C) 2014 Hidetaka Noritomi et al. This is an open access article distributed under the Creative Commons Attribution License, which permits unrestricted use, distribution, and reproduction in any medium, provided the original work is properly cited. In accordance of the Creative Commons Attribution License all Copyrights @ 2014 are reserved for SCIRP and the owner of the intellectual property Hidetaka Noritomi et al. All Copyright (C) 2014 are guarded by law and by SCIRP as a guardian.

\section{ABSTRACT}

The refolding of denatured hen egg white lysozyme (HEWL) was examined by surfactants at a high final refolded HEWL concentration $(1 \mathrm{mg} / \mathrm{mL})$. Hexadecyltrimethylammonium bromide (CTAB) and sucrose fatty acid monoester (DK-SS) were used to dissolve denatured HEWL without denaturants such as guanidine hydrochloride (GuHCl) and urea. When denatured HEWL was perfectly dissolved in buffer solutions containing surfactants and dithiothreitol (DTT), the concentration of CTAB was about one-twentieth times less than that of DK-SS. The concentration of CTAB strongly affected the refolding yield, and the maximum refolding yield was obtained at $0.88 \mathrm{mM}$ CTAB, which is around the critical micelle concentration of CTAB. The refolding yield was influenced by the molar ratio of oxidized glutathione (GSSG) to DTT, and the maximum refolding yield was obtained when [GSSG]/[DTT] was 1.5. The refolding yield was markedly dependent upon the solution $\mathrm{pH}$ of HEWL, and exhibited $80 \%$ at $\mathrm{pH}$ 5.2.

\section{KEYWORDS}

Protein Refolding; Dilution Method; Surfactant; Hen Egg-White Lysozyme

\section{Introduction}

Surfactants are amphiphilic substances that consist of hydrophobic groups and hydrophilic groups [1]. Due to the amphiphilic structure of surfactants, surfactants tend to be adsorbed onto the interfaces between air and water and between oil and water. Consequently, the property of surfactants has been widely applied to cleaning, wetting, dispersing, emulsifying, foaming, anti-foaming, and so on.

Proteins are biomolecules of great importance in the biochemical processes such as the medical, pharmaceutical, and food fields, since they exhibit their outstanding biological activities under mild conditions. However, proteins are easily denatured under unsuitable conditions such as heat and extreme $\mathrm{pH}$ in the process of separation, purification, storage, or enzymatic reaction, and the insoluble aggregate of denatured proteins tends to be formed. Additionally, when using recombinant DNA ex-

\footnotetext{
${ }^{*}$ Corresponding author.
}

pression in bacteria such as Escherichia coli, insoluble inactive aggregated proteins, which are called inclusion bodies, are often formed [2]. Generally, in order to activate denatured proteins, it is first necessary to dissolve the aggregate of denatured proteins in aqueous solutions containing denaturants such as guanidine hydrochloride (GuHCl) and urea. Second, denatured proteins solubilized in aqueous solutions are refolded by diluting an aqueous solution of denatured proteins at a high dilution factor, while preventing dissolved proteins from aggregating, since the renaturation and aggregation processes compete in the process of refolding proteins [3]. In the dilution process, it is desirable that the amount of denaturants added to dissolve the aggregate of proteins is lesser as possible, since high protein concentrations should be kept in the process. From an industrial viewpoint, the reduction of the volume of solutions to be processed would reduce the processing scale, time, and cost. However, the refolding yield tends to decrease with an increase in the final concentration of proteins to be 
refolded.

Additives such as poly (ethylene glycol), salts, sugars, short chain alcohols, and surfactants have been used to effectively refold denatured proteins [3]. These additives bind critical interactive sites of denatured proteins, thereby preventing aggregation and/or misfolding. Especially, surfactants have potential upon the assistance of refolding because of various kinds of them. On the other hand, it has been well known that surfactants such as sodium dodecyl sulfate denature native proteins at high concentrations of surfactants, and are used in the measurement of electrophoresis [4].

In our previous work, we have reported that the waterin-oil (w/o) microemulsion of sucrose fatty acid esters depresses the aggregation of denatured HEWL, and forces denatured HEWL to be refolded [5]. In the w/o microemulsion system, the sufficient recovery efficiency and high refolding yield of renatured lysozyme are obtained. However, the productivity of refolded proteins per volume of w/o microemulsion system is limited due to low overall concentration of proteins in the w/o microemulsion system, since the volumetric ratio of water phase playing a role as the refolding field of proteins is too small. In the present work, we have addressed the question of how the dissolution ability of surfactants affects the refolding of proteins when the dilution method is carried out at the high final protein concentration without denaturants. We have employed hexadecyltrimethylammonium bromide (CTAB) as a surfactant and hen egg-white lysozyme (HEWL) as a model protein, since they are well investigated regarding their structures, functions, and properties $[1,6]$.

\section{Experimental}

\subsection{Materials}

Lysozyme from hen egg whites (HEWL) (EC 3.2.1.17, 46400 units $/ \mathrm{mg}$ solid, MW $=14300, \mathrm{pI}=11)$, Micrococcus lysodeikticus (ATCC No. 4698), and dithiothreitol (DTT) were obtained from Sigma-Aldrich Co. Hexadecyltrimethylammonium bromide (CTAB), ethylenediaminetetraacetic acid (EDTA), oxidized glutathione (GSSG), and guanidine hydrochloride (GuHCl) were purchased from Kanto Chemical Co., Inc. DK-SS (sucrose fatty acids of $99 \mathrm{wt} \%$ monoesters and $1 \mathrm{wt} \%$ diand triesters, fatty acid constituent consisting of $60 \mathrm{wt} \%$ stearic acid and $40 \mathrm{wt} \%$ palmitic acid) was supplied from Dai-Ichi Kogyo Seiyaku. Other reagents were commercially available and used without purification.

\subsection{Denaturation and Dissolution of HEWL}

The protein solution in $50 \mathrm{mM}$ Tris- $\mathrm{HCl}$ buffer at $\mathrm{pH} 8$ containing 1 mM EDTA, 16 mg/L HEWL, 32 mM DTT, and a given amount of CTAB or DK-SS was incubated at $25^{\circ} \mathrm{C}$ for 24 hours.

\subsection{Refolding of Denatured HEWL}

As a typical procedure, the buffer solution containing denatured HEWL, CTAB, and DTT was diluted by 50 $\mathrm{mM}$ Tris-HCl buffer at $\mathrm{pH} 8$ containing GSSG, and was incubated at $25^{\circ} \mathrm{C}$ for 24 hours. After dilution, the final concentrations of HEWL, CTAB, DTT, and GSSG were $1 \mathrm{mg} / \mathrm{L}, 0.88 \mathrm{mM}, 2 \mathrm{mM}$, and $4 \mathrm{mM}$, respectively.

The aqueous solutions used in this study were acetate buffer solutions at $\mathrm{pH} 3.6$ and 5.2, phosphate buffer solutions at $\mathrm{pH} 6$ and 7, Tris-HCl buffer solution at $\mathrm{pH} 8$, borate buffer solutions at $\mathrm{pH} 9$ and 10 . The concentration of buffer solution was prepared at $50 \mathrm{mM}$.

\subsection{Measurement of Aggregation Ratio}

The buffer solution containing aggregates of denatured HEWL was centrifuged at $4000 \mathrm{rpm}$ for $10 \mathrm{~min}$. After centrifugation, the supernatant was measured at $280 \mathrm{~nm}$. The absorption coefficients of native and denatured HEWL were 2.63 and $2.37 \mathrm{~mL} / \mathrm{mg} \cdot \mathrm{cm}$, respectively [7].

The aggregation ratio (A. R.) was defined as follows: A. R. $(\%)=100 \times([$ initial concentration of HEWL $]-$ [concentration of HEWL in supernatant after aggregation])/ [initial concentration of HEWL].

\subsection{Measurement of Remaining Activity and Refolding Yield of HEWL}

The activity of HEWL was determined as follows. After adding $100 \mu \mathrm{L}$ of the aqueous solution containing HEWL to $3 \mathrm{~mL}$ of $50 \mathrm{mM}$ Tris- $\mathrm{HCl}$ buffer at $\mathrm{pH} 8$ containing $200 \mathrm{mg} / \mathrm{L}$ Micrococcus lysodeikticus at $25^{\circ} \mathrm{C}$, the absorbance was continuously measured at $450 \mathrm{~nm}$ by UV/Vis. Bacterial lysis is a first order reaction. The lysis rate constant ( $k$ ) was calculated from the relationship between the absorbance and the reaction time.

The remaining activity (R. A.) was defined as follows: R. A. $=100 \times k$ (of denatured $\mathrm{HEWL}) / k_{o}$ (of native HEWL).

The refolding yield (R. Y.) was defined as follows: R. Y. $=100 \times k\left(\right.$ of renatured HEWL) $/ k_{o}$ (of native HEWL).

\section{Results and Discussion}

\subsection{Dissolution of Aggregates of Denatured HEWL by Surfactants}

In the conventional method of dissolving aggregates of denatured HEWL, denaturants such as guanidine hydrochloride (GuHCl) and urea have been widely used at high concentrations. Consequently, when refolding denatured proteins, the solution of proteins must be diluted 
at a high dilution factor. In the present work, we have employed surfactants instead of denaturants.

Figure 1 shows the relationship of aggregation ratio with surfactant concentration. Any aggregation was not observed when the concentration of CTAB was at 3.5 $\mathrm{mM}$ or over. On the other hand, the solution became transparent when the concentration of DK-SS reached 65 mM. CTAB is a typical cationic surfactant, while DK-SS is a nonionic surfactant. The result indicates that the electrostatic repulsion among protein-surfactant complexes consisting of denatured protein molecules and surfactant molecules enhance the dissolution of proteinsurfactant complexes. Consequently, we have used $\mathrm{CTAB}$ in the following experiments.

\subsection{Denaturation Effect of DTT on Activity of HEWL}

DTT reduces the disulfide bonds of protein molecules. When DTT is used with denaturants such as guanidine hydrochloride ( $\mathrm{GuHCl}$ ) and urea, the denaturation of proteins is promoted [3]. Likewise, when CTAB is used with DTT instead of denaturants, we have assessed the denaturation effect of CTAB on HEWL.

Figure 2 shows the time course of remaining activity

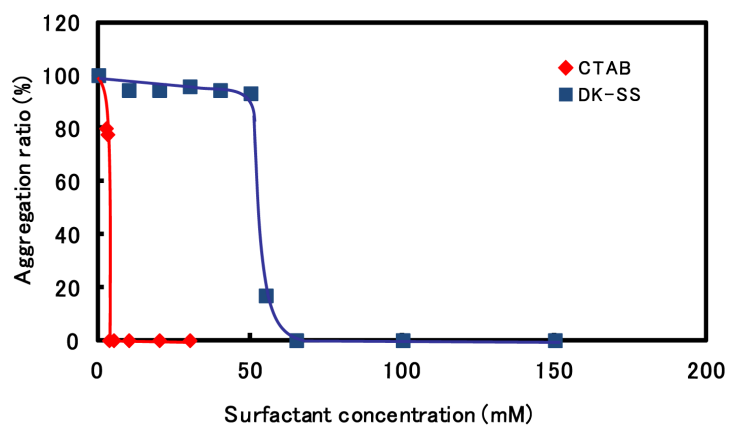

Figure 1. Effect of surfactant concentration on the aggregation ratio of HEWL. A Tris-HCl buffer solution $(50 \mathrm{mM}$ at pH 8) containing $16 \mathrm{mg} / \mathrm{mL}$ HEWL, $32 \mathrm{mM}$ DTT, and a certain amount of CTAB or DK-SS was incubated at $25^{\circ} \mathrm{C}$ for $24 \mathrm{hr}$.

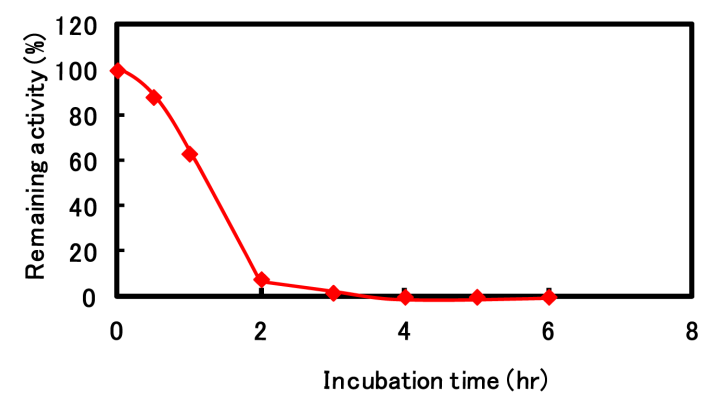

Figure 2. Time course of remaining activity of HEWL. A Tris-HCl buffer solution (50 $\mathrm{mM}$ at $\mathrm{pH} \mathrm{8)}$ containing 16 $\mathrm{mg} / \mathrm{mL}$ HEWL, $32 \mathrm{mM}$ DTT, and $14 \mathrm{mM}$ CTAB was incubated at $25^{\circ} \mathrm{C}$. of HEWL with $32 \mathrm{mM}$ DTT. When the incubation time reached $3 \mathrm{hr}$, the activity of HEWL was not detected in the presence of DTT, while that of HEWL was kept perfectly in the absence of DTT. The solution of HEWL was transparent during the incubation. The result indicates that CTAB itself does not affect the activity of HEWL at the present concentration, but CTAB dramatically influences the activity in the presence of DTT.

\subsection{Time Course of Refolding Yield in Refolding of Denatured HEWL}

The refolding of proteins using dilution method has been carried out by diluting the denatured protein solution to a low final refolded protein concentration (0.01 - 0.1 $\mathrm{mg} / \mathrm{mL}$ ) in order to inhibit the formation in the aggregate of proteins and achieve the refolding of proteins efficiently. However, higher final concentration after the refolding of proteins by dilution is desirable particularly in a large-scale process. In the present work, we have examined the dilution method at a high final refolded protein concentration $(1 \mathrm{mg} / \mathrm{mL})$.

Figure 3 shows the time course of refolding yield. The refolding yield increased with an increase in incubation time, and reached plateau at $24 \mathrm{hr}$. Any precipitation was not observed during the refolding. The time scale of refolding in the present method was similar to that with denaturants in the conventional method [8].

\subsection{Effect of CTAB Concentration on Refolding of Denatured HEWL}

The properties of protein-surfactant complex such as surface tension, rheology, solubilization, and so on are influenced by surfactant concentration [9]. In order to estimate the effect of CTAB concentration on the refolding of HEWL, we have examined the relation between CTAB concentration and the refolding yield of HEWL. As seen in Figure 4, the optimum concentration of CTAB was $0.88 \mathrm{mM}$. Below the optimum concentration, the protein solution became slightly turbid. The optimum

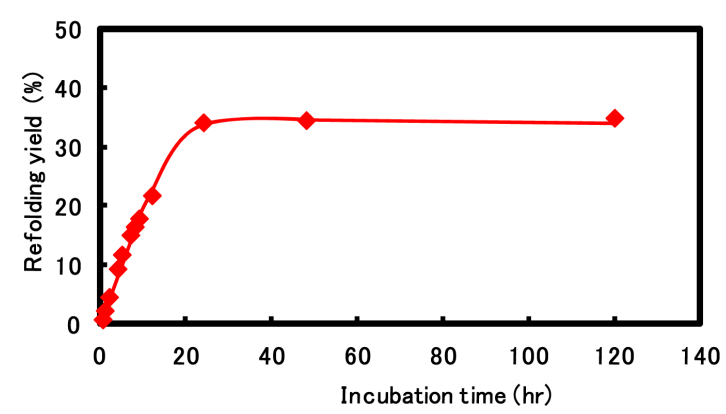

Figure 3. Time course of refolding yield of HEWL. A TrisHCl buffer solution ( $50 \mathrm{mM}$ at $\mathrm{pH} 8$ ) containing $1 \mathrm{mg} / \mathrm{mL}$ HEWL, 2 mM DTT, 4 mM GSSG, and $0.88 \mathrm{mM}$ CTAB was incubated at $25^{\circ} \mathrm{C}$. 


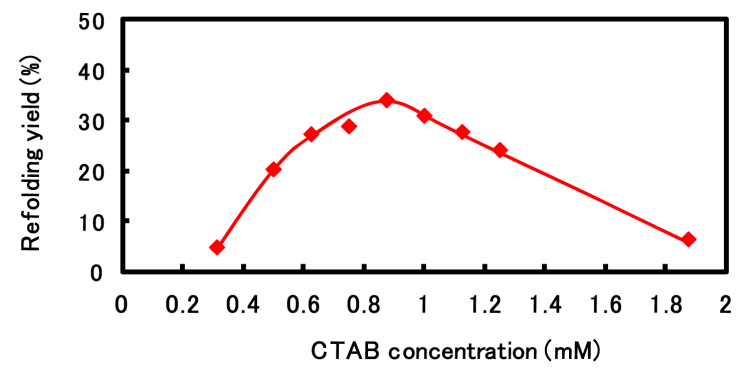

Figure 4. Effect of CTAB concentration on the refolding yield of HEWL. A Tris-HCl buffer solution (50 $\mathrm{mM}$ at $\mathrm{pH} 8$ ) containing $1 \mathrm{mg} / \mathrm{mL}$ HEWL, $2 \mathrm{mM}$ DTT, $4 \mathrm{mM}$ GSSG, and a certain amount of $C T A B$ was incubated at $25^{\circ} \mathrm{C}$ for $24 \mathrm{hr}$.

concentration is around the critical micelle concentration (cmc) of CTAB $(0.98 \mathrm{mM})$ [1]. In general, the solubility of hydrophobic solutes tends to be lower at less than cmc. The result indicates that the amount of CTAB adsorbed on HEWL is not enough to dissolve the protein-surfactant complexes separately at less than the optimum concentration of CTAB. On the contrary, the amount of CTAB molecules adsorbed on a protein molecule is too much over the optimum concentration, and surfactants prevent denatured proteins from refolding.

\subsection{Effect of [GSSG]/[DTT] Concentration on Refolding of Denatured HEWL}

The molar ratio of oxidizing agents to reducing agents is crucial for forming the disulfide bond of proteins accurately $[3,8]$. We have evaluated the optimum molar ratio ([GSSG]/[DTT]) by changing the concentration of GSSG at a constant concentration of DTT.

Figure 5 shows the plot of refolding yield against the concentration of GSSG. The refolding yield sharply increased with an increase in the concentration of GSSG, the maximum refolding yield was observed at $3 \mathrm{mM}$, and then the refolding yield gradually decreased. The optimum molar ratio of [GSSG] to [DTT] was 1.5.

\subsection{Effect of Solution $\mathrm{pH}$ on Refolding of Denatured HEWL}

The structure, function, and property of proteins are strongly dependent upon the solution $\mathrm{pH}$ [4]. In order to estimate the effect of solution $\mathrm{pH}$ on the refolding of denatured HEWL, we have measured the refolding yield at various $\mathrm{pH}$ values.

As shown in Figure 6, the refolding yield markedly depended upon solution $\mathrm{pH}$, and the maximum refolding yield exhibited $80 \%$ at $\mathrm{pH}$ 5.2. As the isoelectric point (pI) of HEWL is 11, the overall charge of HEWL increases in a decrease in solution $\mathrm{pH}$, indicating that the electrostatic repulsion among HEWL molecules increases. The electrostatic repulsion prevents denatured HEWL

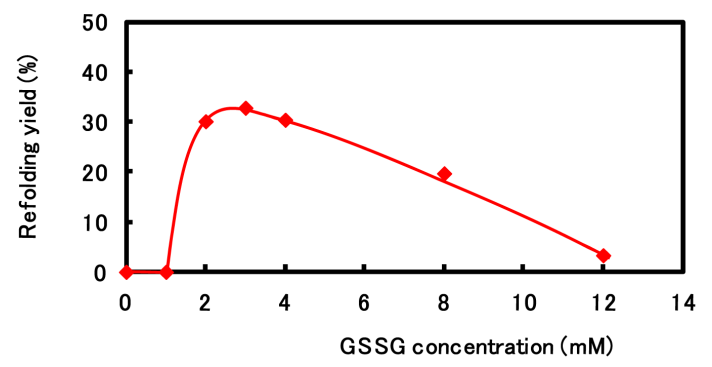

Figure 5. Effect of GSSG concentration on the refolding yield of HEWL. A Tris-HCl buffer solution (50 mM at pH 8) containing $1 \mathrm{mg} / \mathrm{mL}$ HEWL, $2 \mathrm{mM}$ DTT, $0.88 \mathrm{mM}$ CTAB, and a certain amount of GSSG was incubated at $25^{\circ} \mathrm{C}$ for 24 hr.

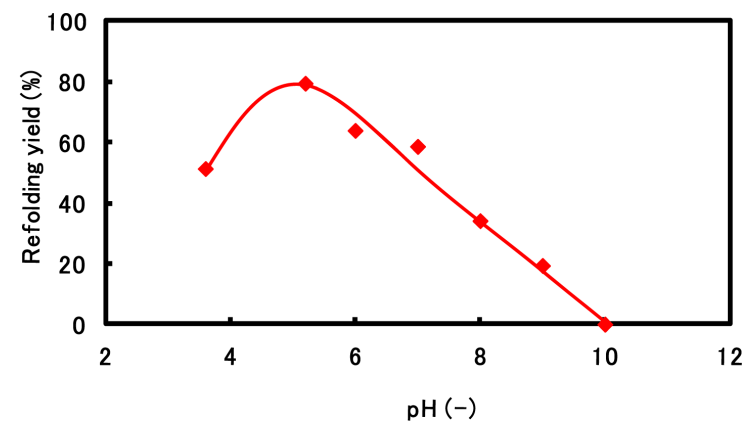

Figure 6. Effect of solution $\mathrm{pH}$ on the refolding yield of HEWL. A buffer solution ( $50 \mathrm{mM}$ at appropriate $\mathrm{pH}$ ) containing $1 \mathrm{mg} / \mathrm{mL}$ HEWL, $2 \mathrm{mM}$ DTT, $4 \mathrm{mM}$ GSSG, and $0.88 \mathrm{mM}$ CTAB was incubated at $25^{\circ} \mathrm{C}$ for $24 \mathrm{hr}$.

from aggregating. Since HEWL is stable in the range from $\mathrm{pH} 5$ to 7 , the maximum refolding yield was obtained in the $\mathrm{pH}$ range. At more acidic $\mathrm{pH}$, HEWL was less stable.

\section{Conclusion}

We have demonstrated that CTAB prevented the formation and growth of aggregates of HEWL, and denatured HEWL was sufficiently refolded at a high final refolded concentration of HEWL. The refolding yield depended upon the concentration of CTAB, the molar ratio of [GSSG] to [DTT], and the solution pH. Especially, the electrostatic repulsion among surfactant-protein complexes was strengthened by the synergy among the charges of CTAB and HEWL molecules, and the denatured HEWL was highly refolded at the optimum $\mathrm{pH}$. Since the final HEWL concentration obtained by the present method is ten to one hundred times greater than that by the conventional dilution method, the present refolding method would be encouraging for its choice in bioindustrial application for protein separation.

\section{Acknowledgements}

The authors thank Dai-Ichi Kogyo Seiyaku Co. Ltd. for 
kindly supplying DK-SS.

\section{REFERENCES}

[1] M. J. Rosen, "Surfactants and Interfacial Phenomena," 3rd Edition, John Wiley \& Sons, Hoboken, 2004. http://dx.doi.org/10.1002/0471670561

[2] F. Franks, "Protein Biotechnology," Humana Press Inc., New York, 1993.

http://dx.doi.org/10.1007/978-1-59259-438-2

[3] E. D. B. Clark, "Refolding of Recombinant Proteins," Current Opinion in Biotechnology, Vol. 9, No. 2, 1998, pp. 157-163.

http://dx.doi.org/10.1016/S0958-1669(98)80109-2

[4] T. E. Creighton, "Proteins Structures and Molecular Properties,” 2nd Edition, W. H. Freeman and Company, New York, 1993.

[5] H. Noritomi, T. Takasugi and S. Kato, "Refolding of Denatured Lysozyme by Water-In-Oil Microemulsions of Sucrose Fatty Acid Esters,” Biotechnology Letters, Vol.
30, No. 4, 2008, pp. 689-693. http://dx.doi.org/10.1007/s10529-007-9587-z

[6] P. Jollès, "Lysozymes: Model Enzymes in Biochemistry and Biology,” 1st Edition, Birkhäuser Verlag, Basel, 1996.

[7] V. P. Saxena and D. B. Wetlaufer, "Formation of ThreeDimensional Structure in Proteins. Rapid Nonenzymatic Reactivation of Reduced Lysozyme,” Biochemistry, Vol. 9, No. 25, 1970, pp. 5015-5022. http://dx.doi.org/10.1021/bi00827a028

[8] Y.-C. Chen, W.-T. Lin, J. W. Wu and H.-S. Liu, "Efficient Lysozyme Refolding at a High Final Concentration and a Low Dilution Factor," Process Biochemistry, Vol. 47, No. 12, 2012, pp. 1883-1888. http://dx.doi.org/10.1016/j.procbio.2012.06.026

[9] E. D. Goddard and K. P. Ananthapadmanabhan, "Interactions of Surfactants with Polymers and Proteins,” CRC Press, New York, 1993. 